\title{
Wallace Spencer Pitcher (1919-2004): an appreciation
}

\author{
Bernard Elgey Leake, FRSE
}

Wallace Pitcher, (or Wally, as he was generally known), who died in the Wirral on 4 September 2004, was born in London on 3 March 1919, and became the leading and most distinguished British expert on granites and their emplacement mechanisms, the geology of Donegal and the Donegal granites and, with John Cobbing, the geology of the Peruvian batholith. He was elected an Honorary FRSE in 1993.

His parents, Harry George and Irene Bertha Pitcher, lived modestly in Acton, west London, although his father was still in the Army when he was born. His father had joined the army before becoming trained and chose to stay in for about two years after the First World War, as work was hard to find; eventually he became a plumber. His mother worked for a time as a dressmaker but was mostly a housewife, as was usual then. He was an only child and went to Hounslow and Bulstrode Schools and, at the age of 13, to Acton Technical School, where he took a matriculation course and also received a good technical education. He showed an early interest in fossils, collecting his first London Clay fossil by the age of ten from a local excavation and, by his early twenties, he was an amateur expert on the Tertiary fauna of the London Clay.

At the age of 17 he became an apprentice assayer for George T. Holloway \& $\mathrm{Co}$, which gave him the training in chemical analysis that was partly responsible for his later first academic appointment. Concurrently, he enrolled as a part-time student at Chelsea College, London, for a degree in chemistry and geology, which combined his main interests. However, the Second World War interrupted these studies and he entered the army. Because he had given his profession as a 'chemist,' this was misunderstood as a 'pharmacist' and he spent the next five years as a medical orderly in the Royal Army Medical Corps. He rarely spoke about this time but when he did, it was clearly no picnic. Early in the war he suffered a leg injury (not a war wound) which led to phlebitis in his left leg and later recurred, so that he worked in the Pathological Laboratory, where his knowledge of chemistry and analytical techniques were useful, and this gained him promotion to a sergeant. He retained his interest in geology, joining the Geologists' Association in 1942, and leading excursions after the war around London. He was invalided out of the Army in 1944 and in 1945 , aged 26 , with a grant to study full-time, he returned to complete his degree at Chelsea under Dr W. F. Fleet, who ran the Geology Department virtually single-handedly. He graduated in 1947 .

In 1947, Professor H. H. Read FRS of Imperial College was seeking to fill a Demonstratorship in Geology with someone able to cope with teaching their somewhat boisterous and, at times, belligerent, ex-servicemen students, whilst also wanting someone who would work with him in studying the origin of the granites of Donegal. Read, a petrologist, was world famous for his trenchant views on the origin of granite as being by granitisation rather than derived as a magmatic rock by magma fractionation, and needed a chemical geologist to be able to elucidate the granitisation process. The analysis of silicate rocks was a slow and skilled job that required much chemical practice to obtain reliable results, and the previous dedicated analyst in the Department, Dr A. W. Groves, had long since retired. The geochemical laboratory, which was not used during the Second World War, had become a cleaners' store and was only revived in 1948 by Donald Bowes (later FRSE) in order to carry out rock analyses for his $\mathrm{PhD}$ project.

Donegal was chosen partly because of a shrewd remark by Professor W. W. Watts of Imperial College to Read at the beginning of the granitisation controversy (which itself was partly generated by Read (1943, 1944)). But it was mainly because Robert M. Shackleton, then a lecturer in the Geology Department of Imperial College and already working in Donegal, confirmed to Read that the mapping of the Donegal Granite by the Geological Survey of Ireland in the 19th Century had revealed an apparent succession of metamorphic rocks enclosed by, and gradually disappearing into, the (Main) Donegal Granite, possibly being transformed into granite. Read interviewed Wally, who had been strongly recommended by Fleet, for the post and asked Wally what research he would undertake if appointed. Wally, whose main geological interest was the Tertiary London Clay, replied 'Tertiary faunas' to which Read's response was negative, but he suggested metamorphic and granitic rocks would be more appropriate as topics that Imperial College specialised in. In fact, Read said, you could start on Monday at 9.30 am if that topic was of interest to you'. After a long pause, Wally replied affirmatively and was duly appointed, this being before Professors had to manipulate appointing committees for even minor posts. The interview ended with Wally being briefly shown a geological map of Donegal and instructed to go and see where best to start mapping some of the numerous granites there. (Read himself not yet being familiar with the ground, as most of his mapping had been carried out in Scotland whilst in the Geological Survey.)

It was again symptomatic of the time that that such an important decision was entrusted to a quite junior man who was also left to choose his PhD area in Donegal, albeit with the guidance and approval of Shackleton, who was nominally in charge of the project until he left a few months later to occupy the Chair of Geology in Liverpool. Read, however, was Wally's supervisor. So, during the Easter break in 1948, accompanied by Stella Scutt, whom Wally had married in August 1947, Wally first went to Donegal with Shackleton, who had a vehicle. Wally and Stella stayed in Meencorwick with the schoolmistress of Thorr school, Nora MacMonagle. At that time conditions were quite primitive, with no tarred roads, piped water, or electricity, and transport was on foot or on a borrowed bicycle. This started a major, 25-year programme of research into the geology of Donegal and its numerous granites, in which dozens of researchers, mainly, but not exclusively, from Imperial College, would become involved. This programme, and the analogous major project on the Moine and Lewisian rocks, also initiated by Read at Imperial College, were the first instances in British Universities of major coordinated field mapping and laboratory geological projects. 
Wally held the post of Demonstrator for one year (194748), an Assistant Lecturership for two (1948-50), and then a Lectureship in Geology at Imperial College for five years (1950-55). Read was his great mentor who taught him much about research methods, whilst Shackleton's perception of the geology of Donegal was inspiring. Wally was a meticulous teacher, very well-liked by his students, as he went to great trouble to prepare his lectures, practicals and field trips carefully; and delivered them in a rather slow methodical way so that even the poorer students could follow and make a good record of the salient facts. He continued his involvement with the Geologists' Association, leading field excursions and an interest in the geology of London and its surroundings. Most important of all his near-London publications was the $G A$ Excursion Guide 30, The London Basin (Pitcher et al. 1958a). His broad geological interests were also emphasised by his joint paper on the loess of Pegwell Bay, Kent and its associated frost soils (Pitcher et al. 1954). His own PhD (1951), on The migmatitic Older Granodiorite of Thorr district, Co. Donegal (Pitcher 1953a), was read to the Geological Society on 9th January 1952, together with his joint paper on the Maas district (lyengar et al. 1953). These marked the beginning of a flood of papers dealing with the Donegal project and were rapidly followed by his study, reported to the Geologists' Association, of the Rosses Granitic Ring Complex (Pitcher 1953b).

In order to understand the emplacement of the Donegal Granites, and their influence on their envelopes, both structural and metamorphic, it was early appreciated that the metamorphic country rocks, as well as the granites, had to be mapped in detail, and all the work was done on 1:10.560 scale maps. This, plus the generally magnificent rock exposure, enabled detailed interpretation. Read was by now approaching retirement and had heavy administrative duties in London and so Wally effectively ran the Donegal project, with some perceptive scientific suggestions from Shackleton (who mapped much of the Fanad Peninsula and Granite but never wrote it up) in mapping the country rocks, which were Shackleton's real interest. The metamorphic rocks turned out to be an extension of the Dalradian rocks of Scotland, the key correlating horizon being the re-discovered (from Kilroe 1907) Portaskaig Boulder Bed (Kilburn et al. 1965), found in Scotland, Donegal, North Mayo and Connemara. Later, the new results obtained from the detailed mapping in Donegal, combined with new work from Connemara and Scotland, enabled the first correlation of the whole Dalradian sequence from Scotland to Connemara to be completed (Harris \& Pitcher 1975). Throughout this period, Pitcher and Shackleton were in close scientific contact over Donegal matters, especially over the location of the Great Glen Fault in Donegal (Dowling et al. 1954) and the tracing of the Portaskaig Boulder Bed, two key discoveries which involved both men.

In order to prove Read's view of the granitisation origin of some or all of the granites, it was necessary to have chemical analyses of the granites and of the country rocks and of their intermediates that were supposedly part way to being chemically changed into granite. The granites, and especially the country rocks, were very varied in composition, so that substantial numbers of samples needed to be analysed to obtain meaningful averages. But each rock analysis took several days to complete and needed considerable analytical skill, which required months to acquire before reliable results could be obtained. Wally was therefore immediately interested when a seminal paper by Shapiro \& Brannock (1952) appeared in a US Geological Survey Circular, detailing a rapid method of silicate analysis involving colorimetric and flame photometric methods, that required less skill and could markedly increase the number of rock analyses completed per week. The equipment was speedily purchased by Imperial College (in the days before applying for research grants delayed progress) and in 1953 (i.e. within a year) a chemist (E. L. P. Mercy) and an Indian geologist (R. C. Sinha) were taken on as research students, working under Wally, to set up and get the new methods working. This was the first attempt in Britain to speed up rock analysis in this way. The writer joined the team from January to July 1954, on secondment from Liverpool University as part of his Liverpool PhD, and this was how he first met and worked under Wally.

There was initially great opposition from petrologists and many silicate analysts to the use of these new rapid methods of rock analysis, allegedly because of their lower accuracy, and this initially worried Wally. But by a fortuitous coincidence, Fairbairn (1951) had just published the results of an extensive investigation into the chemical analyses of a basalt and a granite, which had both been analysed by over 20 of the world's leading silicate analysts, with a deplorable spread of results that completely disproved the supposed accuracy of traditional methods. This gave Wally the confidence to proceed with the new methods, despite the unnerving occasional explosion caused by the mixing of the acetylene and oxygen needed for the flame photometry of the $\mathrm{Na}$ and $\mathrm{K}$. After modification by others, particularly by J. P. Riley (1958) in Liverpool (in whose laboratory the writer worked), the methods eventually became the new standard wet silicate analysis methods, until $\mathrm{X}$-ray Fluorescence analysis became available in the 1960s.

Wally enjoyed field work and he established great rapport with the people of Donegal. The kindly homesteaders would invite him into their small cottages (often still thatched, without electricity or running water and quite unlike their modern replacements), for tea and 'craic', usually tea, boiled eggs and soda-bread with animated conversation. In some areas where the cottages were close together and several stops had already been made that day, Wally found it necessary to crawl past some cottages on hands and knees to avoid further delays to the mapping! Wally early established an outstanding record for looking after and supporting his students, especially the many foreign research students who joined the Donegal project at Imperial College. In this respect he believed in the nurturing, guiding and teaching of those who needed training to gain a good $\mathrm{PhD}$; a characteristic of those teachers who themselves graduated after World War II. Whereas pre-war teaching staff were trained to regard a $\mathrm{PhD}$ as an entirely independent piece of work, chosen, planned and executed entirely independently, which Wally thought was beyond the training and culture of many of the foreign students who came to Britain for postgraduate work.

Dr M. J. Rickard, now retired from the Australian National University, Canberra, wrote (pers. comm. 2005):

'My first contact with Wally was in 1952 when he took our Imperial College first-year class to Ingleton. We learnt his special brand of field mapping; stressing the need to look at every outcrop, whether in a ditch, rubbish dump, house foundation or nettle patch. He took us to the next valley and pointed out a fold that from its plunge should reappear in our mapping area - it did, and I was hooked on structural geology! He was not just a granite man; he told us he had an ambition to visit a pub in every fossil type locality in England. At the end of my first year Wally invited me to join him in Donegal; we stayed in a croft out of Dunglow and took the school bus each day to be dropped off in the middle of a vast bog to 
tramp across the Rosses low granite outcrops back home. He sent me out to different localities to report on what I'd seen, and once to collect skarn minerals for Gregory Bottley's mineral shop. On one occasion he carried me 100 yards across an arm of the sea to save time in removing my boots - Wally always wore shoes! The locals christened him in gaelic "the man of the rocks". For several years, buses stopping at a certain outcrop were met by an old crofter asking if they wanted directions to the junction of G1 and G2!

Later, Wally persuaded me to undertake my $\mathrm{PhD}$ study mapping the structure of the granite envelope in the Errigal area, instead of joining John Sutton's team in the Scottish Highlands. Wally and Prof Read invited us students, myself, Diane Judge (later Knill) and Chris Pulvertaft to a supper at their field HQ in Churchill. They had purchased an old Ford as a field vehicle so that, at Read's insistence, they could commute to their field areas from the local pub that still had an excellent wine cellar. At that time, Wally put his war-time experience as a paramedic to good use in treating my wife for sunstroke; probably the only case in Donegal! I once stayed with the local taacher at Thorr. They remembered Wally well; he had stayed there earlier and later wrote from Liverpool asking them to collect three samples from localities he marked on a map. Well, the husband couldn't prise out the third sample from the glaciated pavement so he sent a rock from the nearby wall ("after all one granite looks like the next"). Wally wrote back to say that one was wrong, so they thought he was a magician.

During his visit to Australia for the Second Hutton Symposium, Wally acted as a wise adjudicator and peacemaker during the often acrimonious field discussions. His professionalism, kindness and ability to see both sides of a geological argument are reflected in his many publications. He has been a mentor and an inspiration for several generations of geologists.'

Ironically, as the Donegal work progressed it became apparent that virtually all the Donegal granites had been intruded as magmas, and no granitisation, other than marginal magmatic effects, was found. The Thorr pluton work of Wally's with its migmatitic title (Pitcher 1953a) reflected the initially strong Read influence, and it later fell to Wally's diplomatic skills to persuade the strongly dogmatic Read that the results of the project had been to demonstrate the opposite of his often expressed and firmly-held views! This was not easy and few ever gave Wally the credit for managing this in their joint Pitcher et al. (1958b) study of the Main Donegal Granite and that of its aureole (Pitcher \& Read 1960) with its surprising mixture of kyanite, staurolite, andalusite and garnet. The work with Sinha was based on over 100 chemical analyses in a series of traverses across the aureole of the Ardara Pluton and was the first really rigorous demonstration of the isochemical nature of contact metamorphism that took into account the original variability of the composition of the metasediments (Pitcher \& Sinha 1957). The whole project produced results that had international significance and interest. In particular, it demonstrated that the level in the crust at which a granite was emplaced is not the sole, or necessarily the most important, control over the type of emplacement, as a wide variety of emplacement modes and means of making space for the emplacement of granitic magma were demonstrated to have occurred at much the same crustal level in Donegal; whereas Read had supposed crustal level to be a crucial factor in determining granite type. In one sense Read was correct. Granitisation was not disproved in Donegal; it was simply not proved there. By the 1960 s it had become widely accepted as a process operating in the lower crust, where partial melting and migmatisation resulted from very high grade metamorphism, a situation Read had long ago espoused. Donegal was upper crust and not the right place to find the source of the granites. The identification of 'ghost stratigraphy' as stoping selectively left remnants of the country rock successions, and the very varied mechanisms of emplacement of the granite plutons were major aspects of the results of the project. The summary of the Donegal results appeared in 1972 in the great book whose title reflected what had been found, not what had been looked for: The Geology of Donegal; a study of granite emplacement and unroofing (Pitcher \& Berger 1972), together with the most detailed geological map of Donegal ever produced, drawn by Margaret Spencer. This confirmed Wally's stature as the leading British expert on granites and their emplacement.

In 1955 Wally moved to King's College London as Reader in Geology and it was during this time that his interest in the Nigerian granites was aroused, perhaps because of the publication by Jacobson et al. (1958) of the first Geological Society Memoir which concerned the intriguing Ring Complexes in the Younger Granite Province of N. Nigeria. Although too heavily committed to the Donegal work to undertake much in Nigeria, he started students such as D. C. Turner on projects which yielded much about the relationships of volcanic and plutonic rocks, the curious ring dykes and the alkaline and peralkaline rocks and what later became known as the A-type granites. In 1962 he was appointed to the George Herdman Chair of Geology in the University of Liverpool, following Shackleton, who had moved to Leeds University. Wally's appointment at Liverpool maintained the close links between the Liverpool and Imperial College Departments that had characterised the 'reigns' of Boswell, Read and Shackleton before him. Wally remained at Liverpool University until and after his retirement in 1981, continuing researching after 1981 as vigorously as before.

In Liverpool he was jointly responsible for a major symposium in 1964 on The Controls of Metamorphism which resulted in 1965, with G. W. Flinn, in a book of that title (Pitcher \& Flinn 1965). A great supporter and regular attender at the meetings of the Liverpool Geological Society his influence is also apparent in the 9-11 January 1969 Liverpool symposium on the Mechanism of Igneous Intrusion, which again produced a notable book, edited by Newall \& Rast (1970). He initiated a major study of the Peruvian batholith, involving arduous field work, again with a number of other researchers, including 13 Liverpool PhD students, but in particular with Dr John Cobbing, of the now-named British Geological Survey. The field work was carried out at high altitudes, often under extreme temperatures, using tents, horses, walking and Land Rovers in an arid region (the opposite of Donegal!), with very primitive facilities, which was not easy for a man approaching 60. The topography enabled the three-dimensional shape of the tops of some of the constituent plutons to be observed in a way not possible in Donegal. As so much less is generally known about this project than the Donegal work, the following general picture is included.

Dr John Cobbing wrote (pers. comm. June 2005):

'Long before I knew Wallace personally I was hearing stories of his work in Donegal and some of his eccentricities. On one occasion during a meeting at the Geological Society he produced, apparently from nowhere, a large mullion [a stick-shaped rock] and 
spoke of the significance of the structures and tectonic setting which had formed it. For me at that time he was a remote and somewhat awe inspiring figure. ... Later, I was sent to Peru to join a small British team with the Peruvian Geological Survey. ... I was given the task of mapping a slice of six quadrangles across the Western Cordillera extending from the coast to the Altiplano at $\sim 4500 \mathrm{~m}$. I was given a great pile of aerial photographs, from which I made a huge tracing of all the visible geological features, one of which was a segment of the granitic Coastal Batholith, which I could see was made up of a number of different plutons distinguishable on the photos. While I was doing this, Wallace arrived in Lima with the objective of studying the batholith in part of the region to which I had been assigned by the Survey. He decided to begin work in the Rio Huaura valley about $130 \mathrm{~km}$ north of Lima and he went there with Ciro Hudson, a Peruvian student as his field assistant.

As events progressively unfolded, and we became more attuned to working in the desert and gaining familiarity with the Coastal Batholith, the area of our combined efforts was gradually extended both to north and south, until eventually the greater part of that huge batholith had been geologically mapped, and a number of supporting studies, including geochemistry, geophysics and isotopic dating had been completed, involving many workers. ... The chief factor which enabled the elucidation of the Coastal Batholith is that all the component plutons are located in the coastal desert, where there is almost perfect exposure and where good use can be made of aerial photographs both before and during field work. However, although the gross outlines of the granitic components of the batholith can be determined in this way, the defining feature of the granites is their textural variation, which can only be determined on the ground by careful observation. It was with respect to this factor that Wallace, with his former experience in Donegal, was able to gather the strands of contrasting observations made by his students into a coherent whole which established distinctive patterns of textural variation for almost the whole outcrop of the batholith. One of the most striking features of the Coastal Batholith is the alignment of four ring complexes over a $160 \mathrm{~km}$ sector of the batholith north of Lima. ... In the great diversity of granites worldwide, it can be truly said that Wallace has done more than most of us in unravelling the problems. However, it will be as a dear friend and colleague, that he will be more truly remembered.'

This study of a supra-subduction zone batholith related to the Pacific margin generated many papers and culminated in the book Magmatism at a Plate Edge: the Peruvian Andes (Pitcher et al. 1985), which showed that Wally was still the leading British granite expert.

Dr W. E. Stephens FRSE recently (26 December 2005) wrote:

'If any of Wally's major achievements has been understated it is probably the Peruvian work. Although the USGS had published maps and reports on segments of continental are batholiths, Wally's book on the Peruvian batholith was the first (and probably still the best in field terms) study of a major young cordilleran-type batholith using modern techniques. I felt its profound impact at the time. There was nothing quite like it that you could go and lift from a shelf. Although petrogenetic models for batholiths are constantly being debated and refined, Wally's field models of emplacement and the evolution of this batholith still stand essentially intact. Also his insights into the volcanic-plutonicsedimentary basin-tectonic inter-relationships on a regional scale were ground breaking. Had he been backed by a first class geochronological laboratory I think he would also have made a classic contribution to upper crust formation in continental arcs.'

It was during these years that Wally gradually became an international, geological statesman on granites. He was one of the members of the Circum-Pacific Plutonism Project, led by P. C. Bateman, the US Geological Survey expert on the Sierra Nevada batholith of California, and with this group travelled the world examining granites of different types and ages. On one such occasion, when they were in Santiago, Chile, the Allende Government was overthrown and the group, led by Luis Aguirre, took their excursion bus up to the border with Argentina and finally managed to escape by driving the bus through a railway tunnel into Argentina.

Wally was a big man physically, but a calm, generally unruffled, hard-working, rather ponderous-speaking, impeccably-mannered, gentlemanly type who did not easily make difficult decisions and often worried inwardly about them afterwards. He had a characteristic chuckle that always remained with him upon hearing of an amusing incident. He would occasionally lightly rest his arm on the shoulders of an old student as a mark of affection as he advised, requested or told them of an incident. Although not a religious man, he had a strong sense of moral values and what was right and what was not and was a great conciliator and very unassuming. Being a Londoner, he certainly missed the easy access to many society meetings when he moved to the Wirral.

Despite the substantial administrative load of running one of the biggest Geology Departments in the country, he gave major service to the geological profession in a variety of ways. He became a member and then Chairman of the NERC Geological Sciences Research Grants Committee, serving from 1974 to 1981 . He was also President of Section C of the 1979 British Association Meeting. But most of all, he was significantly responsible for extricating the Geological Society from the 1960s mess of a journal that appeared over a year late. publication print runs that far exceeded sales, the alienation of many who wanted to form specialist groups and persistent financial deficits that threatened the Society's existence. Wally became a Secretary (1970-73), Foreign Secretary (1974-75). and then President (1977-78) but his service started before 1970 . This was a very heavy commitment with the numerous meetings involved, as return between London and the Wirral involved a minimum of nine hours travel, door to door, incurring early starts and tired late returns which his family certainly felt. In particular, he supported the transformation of the Quarterly Journal of the Geological Society into the bimonthly Journal of the Geological Society and the move to Douglas Grant and the Scottish Academic Press, and asked the writer to help by joining the Journal's Editorial Subcommittee in late 1968. With the writer, he bitterly opposed the ditching of Douglas Grant as the Society's publisher in favour of Blackwells Scientific Publishers. Almost alone he was responsible for persuading the Geological Society Council to be flexible enough to have various types of Specialist Groups, 
including affiliated groups in which neither the members nor the Officers had to be Geological Society members. By this means he kept the Society from falling apart as successive Specialist Groups were formed and instead it became the 'umbrella' under which many groups clustered. His two Presidential addresses, The anatomy of a batholith (1977) and The nature, ascent and emplacement of granitic magmas (1978) are among the now diminishing number of great Presidential addresses, and drew heavily on his Peruvian discoveries. He received the Lyell Fund in 1956, the Bigsby Medal in 1963, and the Murchison Medal in 1979 from the Geological Society.

Wally was a founder member and Aberconway Medallist (1983) of the Institution of Geologists, being one of the signatories on the 1974 Geological Society Working Party that resulted in the formation of the professional Institution of Geologists, even if their estimate of a minimum membership of 5000 within five years of its initiation proved to be stunningly erroneous! (In 2004, 30 years after 1974, it was approaching 2500). An excellent example of the wrong numbers persuading the Council to do the right thing, as they probably would not have agreed if the actual numbers had been known in 1974. He became FGS in 1945 and remained a Fellow for 59 years until his death. He joined the Mineralogical Society in 1949 and remained a life-long member. Among his little known mineralogical successes was preserving the Donegal beryl locality. He was a life-long member of the Geologists' Association from 1942, eventually (1973) becoming an Honorary Member. He was a Fellow of the Institution of Mining and Metallurgy. He was the recipient of many other honours, being an Honorary Fellow of the Geological Society of America (1982), Honorary MRIA (1977), Honorary FRSE (1993) and, apart from an earned DSc (London 1964), held Honorary DSc degrees from Dublin (1983) and Paris-Sud (1993), and was awarded the Silver Medal of the Liverpool Geological Society (1964) and the University Medal of Helsinki in 1986.

Wally was Head of the Geology Department in Liverpool from 1 October 1962 to 30 September 1978. In his early years in Liverpool University, he implemented a scheme agreed by Shackleton and Professor J. M. Cassells FRS of Physics, of the first geophysics degree in Britain. Dr J. C. Harper continued to act as academic administrator, a role he had carried out for many years under Shackleton, leaving Wally with much time for teaching and research. Wally and his wife put much effort into entertaining members of the Department to foster good relationships which helped to create a cooperative esprit de corps across the different interest groups within the Department (a difficulty Imperial College never resolved because of the widely scattered commuting in London). A summer garden party was held at their home in Upton, with a hired marquee, games, food and drinks and everyone in the Department, secretaries, technicians, senior students, academic staff and children were invited. A great many students remember this with great affection. A staff Christmas party was held and other social events which helped integrate staff and students. In the halcyon days of the sixties, the Department of Geology, under Wally, continued, as under Shackleton, to inspire an astonishing number of students to follow academic, Geological Survey and industrial posts in geology, many more than most Geology Departments in other Universities.

Lack of space in the post-World War I-built Jane Herdman Laboratories became an increasing constraint, only slightly mitigated by the acquisition and adaptation of the adjoining houses in Brownlow Street. As the financial cuts of the 70 s began to affect student field work, staffing and research, Harper had retired, and running the Department became a much more burdensome matter, requiring strategic and manipulative administration quite unlike that which traditionally Professors had been called to undertake or which most felt should be a Professor's priority before research and teaching. At the same time, the external pressures of part-running the Geological Society and NERC Research Grants Committee, giving innumerable invited lectures, continuing his field work in Peru, supervising his research students, continuing his external examining and undergraduate teaching, together with all the travelling involved in all but the last, did not make it easy to attend all the ballooning numbers of meetings required to protect the back of the Department from cuts. Wally did not like or excel at this and running the Department did not give the satisfaction it had previously. The calls to represent the Department extra-murally brought much reflected glory to it, but clashed directly with the need to be on the ground, bean counting, and he resigned as Head of Department in 1978. As resources given to Departments became more precisely measured to student numbers and research income, those Departments whose Professors had previously secured good libraries and generous staffing etc. suffered the most. With the staff reductions forced on the Universities by the Thatcher Government, Wally volunteered for formal early retirement at age 62 in 1981 in exchange for a promise by the University to refill the Chair. It was typical of the changed environment, that because Wally did not get the precise date when this would be carried out, it was not implemented for several years, much to Wally's disgust, as also was his reaction to the later lack of space in the Department to accommodate him. Although he had retired long before the Oxburgh Review and the implementation of research gradings for Departments, and although others were responsible for successfully manoeuvring the Department into the top grade, there is no doubt that Shackleton and Pitcher had built the Department up for over 30 years so that it could achieve this success with a final, but critical, push. Wally obtained a Leverhulme Emeritus Fellowship (1981-83) to write up the Peruvian work which appeared in 1985 , as already cited.

After this Wally, working from home, combined his enormous knowledge and experience of granites with the published literature on granites, to produce another major book, The Nature and Origin of Granite (1993), which went into a second edition in 1997 when he was no less than 78, a considerable achievement. To his great pleasure, his 70 th birthday was marked by a Special Symposium in Liverpool on Granite on 6 and 7 January 1990 that resulted in publication in the Geological Journal (vol. 25, Parts 3 and 4, 1990). In this volume with an international array of authors, there is a photograph of Wally at 70 years and an account of his scientific work up until then by Brown (1990).

He remained active in research, especially over Donegal geology and, for instance, organised the field excursions to Donegal both before and after the first Hutton Granite Symposium which the Royal Society of Edinburgh initiated in 1987. He was delighted when the structural geologist Donny Hutton, to whom he became quite close, was able to explain how major sinistral faulting created the space for the Main Donegal Granite magma to fill; thus answering a problem that had long perplexed petrologists generally over granite batholiths, and incidentally removing one of the problems that the granitisation theory had sought to answer. Wally's next to last visit to Donegal, in June 2002, was by chauffeur-driven car from the Wirral, accompanied by his wife and with Donny Hutton as chauffeur, at the expense of a Massachusetts Institute of Technology research project, which needed him to 
select the best localities and material for isotopic and chemical analyses. A luxurious contrast to the first visit!

His last service to the Geological Society was to gather, in 1998-89, a series of recollections by those involved in modernising the Society in the 1960 s to 1980 s which are now in their Archives and have been partly used in writing the bicentennial history of the Society. He was a regular attender at the Liverpool Geological Society's meetings right to the end and the writer was privileged to stay with him and Stella after lecturing to that Society in early 2004 . His last major publication was $A$ Masterclass Guide to the Granites of Donegal (Pitcher \& Hutton 2003), which he was just able to launch officially in Galway in Spring 2004, a few months before his death from leukaemia. His final publication was an Invited Comment on J. D. Clemen's (2005) paper on Granites and granitic magmas. His immense collection of granite literature has gone to Kingston University because of the staff research in this field. He was, a courteous, hard-working, productive, kindly and modest man who would have been the first to deny charismatic brilliance, but who many remember with great affection.

His wife of 57 years, Stella, née Scutt, whom he married in 1947 and with whom he had two sons and two daughters, Margaret, John, Robert and Elizabeth (and grandchildren Kate, Faye and Daniel Pitcher) was an inestimable help and support to him and was undoubtedly indirectly responsible for much of his success.

\section{Acknowledgements}

I wish to thank Stella Pitcher for providing much helpful information and corrections.

\section{References}

Brown. G. 1990. Wallace Spencer Pitcher: the geologist. Geological Journal 25, 211-13.

Clemens, J. D. 2005. Granites and granitic magmas. Proceedings of the Geologists' Association 116, 21-3.

Dowling, J. W. F., Shackleton, R. M., Pitcher, W. S., Cheeseman, R. L. \& Read, H. H. 1954. The Great Glen Fault, Co. Donegal. Geological Magazine 91, 519-20.

Fairbairn, H. W. 1951 A cooperative investigation of precision and accuracy in chemical, spectrochemical and modal analysis of silicate rocks. US Geological Survey Bulletin 980

Harris, A. L. \& Pitcher, W. S. 1975. The Dalradian Supergroup. In Harris, A. L., Shackleton, R. M., Watson, J., Downie, C., Harland, W. B. \& Moorbath, S. (eds) A Correlation of the Precambrian rocks of the British Isles. Geological Society, London, Special Report 6, 52-75.
Iyengar, S. V. P., Pitcher, W. S. \& Read, H. H. 1953. The plutonic history of the Maas area, Co Donegal Quarterly Journal of the Geological Society 110, 203-28.

Jacobson, R. R. E., MacLeod, W. N. \& Black, R. 1958. Ring complexes in the Younger Granite Province of Northern Nigeria Memoir of the Geological Society, London 1.

Kilburn, C., Pitcher, W. S. \& Shackleton, R. M. 1965. The stratigraphy and origin of the Portaskaig Boulder Bed Series (Dalradian). Geological Journal 4, 343-60.

Kilroe, J. R. 1907.The Silurian and metamorphic rocks of Mayo and north Galway. Proceedings of the Royal Irish Academv 26B. $129-60$.

Newall, G. \& Rast, N. (eds) 1970. Mechanism of Igneous Intrusion. Geological Journal Special Issue 2. Liverpool Geological Society.

Pitcher, W. S. 1953a. The migmatitic Older Granodiorite of Thorr district, Co. Donegal. Quarterly Journal of the Geological Society 110, 41346.

Pitcher, W. S. 1953b. The Rosses Granitic Ring Complex, County Donegal. Proceedings of the Geologists' Association 64, 153-82.

Pitcher, W. S. 1977. The anatomy of a batholith. Journal of the Geological Society 135, 157-82.

Pitcher, W. S. 1978. The nature, ascent and emplacement of granitic magmas. Journal of the Geological Society, London 136, 627-62.

Pitcher, W. S. 1993. The Nature and Origin of Granite. London \& New York: Chapman \& Hall. [2nd edition, 1997.]

Pitcher, W. S., Shearman, D. J. \& Pugh, D. C. 1954. The loess of Pegwell Bay, Kent, and its associated frost soils. Gieological Magazine 91, 308-14

Pitcher, W. S., Peake, N. B., Carreck, J. N., Kirkaldy, J. F., Hester. S W. \& Hancock, J. M. 1958a. The London Region. Geologists Association Guide 30. London: The Geologists' Association.

Pitcher, W. S., Read, H. H., Cheeseman, R. L., Pande. I. C. \& Tozer. C. F.1958b. The Main Donegal Granite. Quarterly Journat of the Geological Society 114, 259-305.

Pitcher, W. S., Atherton, M. P., Cobbing, E. J. \& Beckinsale, R. D) 1985. Magmatism at a plate edge: the Peruvian Andes. Giasgow: Blackie; New York: Halstead Press.

Pitcher, W. S. \& Berger, A. R. 1972. The Geology of Donegal; a study of granite emplacement and unroofing. New York: Wiley Interscience.

Pitcher, W. S. \& Flinn, G.W 1965. The Controls of Metumorphism. Geological Journal Special Issue 1. Edinburgh and London: Oliver and Boyd.

Pitcher, W. S. \& Hutton, D. H. W. 2003. A Masterclass Guide to the Granites of Donegal. Dublin: Geological Survey of Ireland.

Pitcher, W. S., \& Read, H. H. 1960. The aureole of the Main Donegal Granite. Quarterly Journal of the Geological Society 116, I-36.

Pitcher, W. S. \& Sinha, R. C. 1957. The petrochemistry of the Ardara aureole. Quarterly. Journal of the Geological Society 113, 393-408.

Read, H. H. 1943. Meditations on Granite. Part I (Presidential Address 1943). Proceedings of the Geologists" Association 54, 64-85.

Read, H. H. 1944. Meditations on Granite. Part II (Presidential Address 1944). Proceedings of the Geologists' Association $\mathbf{5 5}$, 45-93.

Riley, J. P. 1958. The rapid analysis of silicate rocks and minerals. Analytica Chimica Acta 19, 413-28.

Shapiro, L. \& Brannock, W. W. 1952. Rapid analysis of silicate rocks. US Geological Survey Circular 165.

BERNARD ELSEY LEAKE, School of Earth, Ocean and Planetary Sciences, Main Building, Cardiff University, Cardiff, Wales CF10 3YE. 